\title{
PERENCANAAN PROYEK PEMBUATAN HYDRANT HOUSE MENGGUNAKAN METODE PERT-TYPE SYSTEM PADA DEPARTEMEN SIPIL PT XYZ
}

\author{
Muhammad Harits Fakhruddin ${ }^{1}$, Elly ismiyah ${ }^{2}$, Hidayat $^{3}$ \\ Program Studi Teknik Industri, Fakultas Teknik, Universitas Muhammadiyah Gresik \\ Jl. Sumatera 101 GKB, Gresik 61121, Indonesia \\ e-mail: haritsfakhruddin@gmail.com
}

\begin{abstract}
ABSTRAK
Proyek Hydrant House adalah jenis proyek konstruksi yang membuat area tanki tandon air bawah tanah, beserta instalasi pompa utamanya. Proyek Hydrant House tersebut akan dikerjakan oleh tim internal perusahaan, yaitu Departemen Sipil PT XYZ. Terkait lama pengerjaan proyek Hydrant House, pihak manajemen memberi target selama kurang lebih 3 bulan. Namun, lama waktu tersebut dapat ditinjau ulang dengan catatan Departemen Sipil PT XYZ dapat melampirkan rincian perhitungan schedule dari proyek tersebut. Sejauh ini Departemen Sipil PT XYZ dalam merencanakan proyek hanya berdasarkan metode scheduling sederhana dan pengalaman saja. Perlu dilakukan perencanaan yang lebih sistematis dan terukur agar dapat mencegah terjadinya permasalahan di kemudian hari. Jadi, dalam melakukan penelitian terkait perencanaan proyek, penulis akan menggunakan metode PERT-Type System. Dari penelitian ini dapat diperoleh kesimpulan, yaitu : terdapat tiga level (proyek, tugas, sub-tugas) dari proyek Hydrant House dan dari tiga level tersebut terdiri dari 34 sub-tugas. Terkait lama proyek dapat terselesaikan adalah selama 120 hari, dengan probabilitas keberhasilan sebesar 12\%. Oleh karena itu, penulis memberi opsi peluang keberhasilan terselesainya proyek sebesar 95\% adalah selama 139.23 hari atau 140 hari. Jadi, agar dapat tercapai penyelesaian proyek, maka proyek paling tidak harus dikerjakan selama 140 hari. Karena probabilitas penyelesaian 140 hari lebih besar (95\%), jika dibandingkan dengan probabilitas penyelesaian 120 hari (12\%). Kemudian diketahui lintasan kritis pada proyek Hydrant House adalah yang dilalui oleh alur 1-6-7-8-9-10-11-12-13-14-15-16-17-18-19-20-22-23-24-25-26-27-29-30-31
\end{abstract}

Kata kunci: Proyek, Hydrant House, Departemen Sipil, Work Breakdown Structure, CPM, PERT.

\begin{abstract}
The Hydrant House project is a type of construction project that creates a tank area underground water reservoir, along with the main pump installation. Hydrant House Project will be carried out by the company's internal team, namely the Civil Department of PT XYZ. Regarding the duration of the Hydrant House project, the management gave: target for approximately 3 months. However, the length of time can be reviewed with the record that the Civil Department of PT XYZ can attach details calculation of the schedule of the project. So far the Civil Department of PT XYZ in planning projects based only on simple scheduling methods and experience only. A more systematic and measurable planning is needed in order to prevent problems from occurring in the future. So, in conducting research related to project planning, the author will use PERT-Type System method. From this research, conclusions can be drawn, namely: There are three levels (project, task, sub-task) of the Hydrant House project and of the three levels consist of 34 sub-tasks. Regarding the length of the project can be completed is 120 days, with a probability of success of 12\%. Therefore, the author gives the option of a successful completion opportunity project by $95 \%$ is for 139.23 days or 140 days. So, in order to completion of the project is achieved, then the project must be carried out for at least 140 days. Since the probability of completion of 140 days is greater (95\%), if compared to a 120-day (12\%). Then It is known that the critical path in the Hydrant House project is the one traversed by the path

1-6-7-8-9-10-11-12-13-14-15-16-17-18-19-20-22-23-24-25-26-27-29-30-31
\end{abstract}

Keywords: Project, Hydrant House, Civil Department, Work Breakdown Structures, CPM, PERT.

Jejak Artikel

Upload artikel : 15 Desember 2021

Revisi : 25 Desember 2021

Publish : 31 Januari 2022 


\section{PENDAHULUAN}

Proyek dapat didefinisikan sebagai suatu rangkaian kerja dalam suatu organisasi yang bersifat sementara untuk tercapainya tujuan organisasi, dengan memanfaatkan SDM maupun non SDM (Ratensalu, 2019). Suatu proyek dapat dipastikan memiliki karakteristik "Sementara", yang mana didefinisikan setiap proyek memiliki jadwal yang jelas dan tahu kapan akan berakhir. Jika tujuan dalam proyek sudah tercapai atau kebutuhan pada proyek itu tidak ada lagi, maka proyek dianggap sudah selesai atau close. Kemudian karakteristik selanjutnya adalah "Unik", yang mana dapat didefinisikan setiap proyek menghasilkan suatu produk, solusi, service, atau output tertentu yang berbeda-beda satu dan lainnya. Dan karakteristik terakhir adalah "Progressive elaboration", yang mana dapat didefinisikan setiap proyek terdiri dari step by step yang terus berkembang dan berlanjut hingga memperjelas semakin dekatnya proyek akan berakhir (Project Management Institute, 2004).

Menurut Dimyati dan Nurjaman (2014), Manajemen proyek merupakan proses merencanakan, mengorganisasikan, memimpin, dan mengendalikan kegiatan anggota organisasi serta sumber daya lainnya sehingga dapat mencapai sasaran organisasi telah ditentukan sebelumnya. Dalam merencanakan, melaksanakan, dan mengevaluasi suatu proyek diperlukan manajemen yang baik, agar output suatu proyek sesuai dengan ekspetasi masingmasing pihak yang terkait.

PT XYZ merupakan perusahaan yang bergerak dibidang wood furniture manufacture. memproduksi indoor furniture yang bergaya minimalis khas Jepang. Produk yang dihasilkan berupa rangkaian part-part yang nantinya dapat dirakit secara custom oleh customer. Sehingga dapat dibuat banyak variasi sesuai dengan keinginan dan kebutuhan customer. Untuk saat ini, produk dari PT XYZ hanya dijual secara ekspor ke customer yang berada di Jepang, Perancis, Australia, dll.

Perusahaan terus melakukan perkembangan secara berkala sehingga luas area gudang yang mana digunakan untuk stok bahan baku, stok Work In Progress, dan stok finish good semakin meningkat. Oleh karena hal tersebut, perusahaan menyadari terkait penggunaan bahan baku yang sebagian besar berbahan dasar kayu adalah mudah terbakar. Disisi lain karena luasnya area perusahaan, maka akan menjadi masalah jika suatu hal yang tidak diinginkan (kebakaran) telah terjadi. Maka dari itu perusahaan berencana menambah titik sumber air sebagai tindakan antisipasi jika terjadi kebakaran, dengan cara membuat proyek Hydrant House.

Proyek Hydrant House adalah jenis proyek konstruksi yang membuat area tanki tandon air bawah tanah, beserta instalasi pompa utamanya. Hydrant House berbentuk seperti rumah atau pos pada umumnya, dengan simpanan air pada bagian bawah tanah. Tujuan dibuat Hydrant House, seperti yang telah dijelaskan secara umum di atas adalah untuk menyuplai air ke pipa-pipa hydrant yang tersebar di tiap gudanggudang perusahaan. Sehingga diharapkan persediaan air selalu dalam keadaan standby, tanpa mengandalkan suplai PDAM, jika musibah (kebakaran) telah terjadi. Proyek Hydrant House tersebut akan dikerjakan oleh tim internal perusahaan, yaitu Departemen Sipil PT XYZ. Terkait lama pengerjaan proyek Hydrant House, pihak manajemen memberi target selama kurang lebih 3 bulan. Namun, lama waktu tersebut dapat ditinjau ulang dengan catatan Departemen Sipil PT XYZ dapat melampirkan rincian perhitungan schedule dari proyek tersebut. Pada gambar 1, 2, dan 3 adalah bentuk Hydrant House yang akan dibuat.

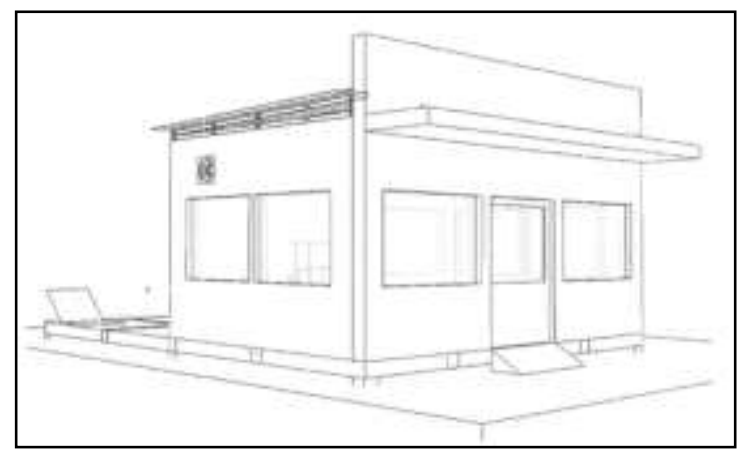

Gambar 1. Hydrant House (Tampak Luar) Sumber : Departemen Sipil PT XYZ (2021)

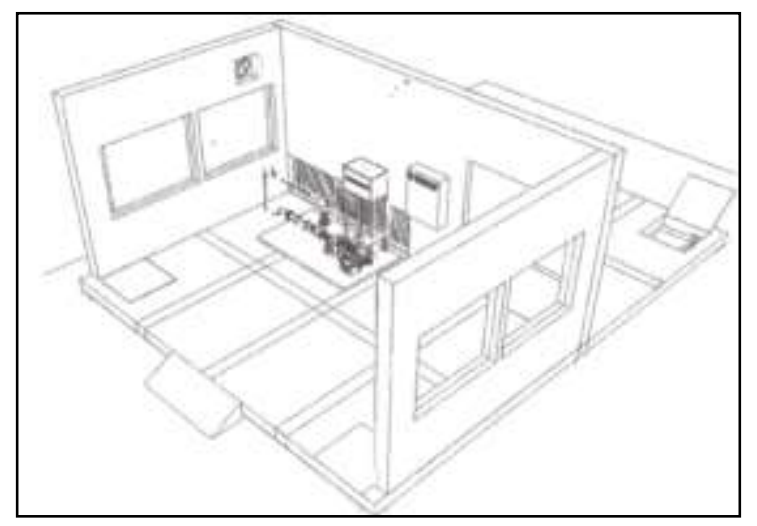

Gambar 2. Hydrant House (Tampak Dalam) Sumber : Departemen Sipil PT XYZ (2021) 


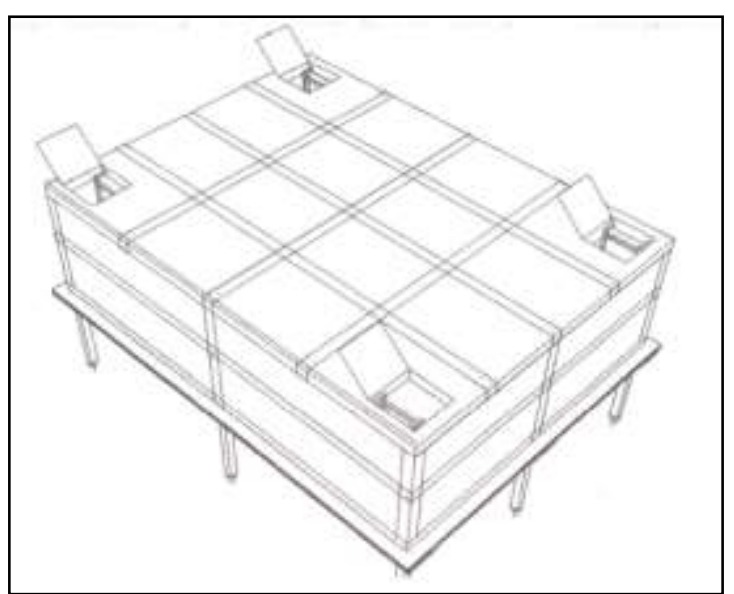

Gambar 3. Tanki Hydrant House Bagian Bawah Sumber : Departemen Sipil PT XYZ (2021)

Departemen Sipil PT XYZ bergerak pada proyek-proyek pembuatan, perbaikan fasilitas perusahaan. Banyak pekerjaan yang berkaitan dengan konstruksi, baik yang berskala kecil maupun yang berskala besar. Departemen tersebut dapat dikatakan cukup banyak menerima proyek-proyek internal perusahaan, mengingat perusahaan dalam tahap ekspansi untuk memperbanyak dan memperluas proses produksi. Proyek Hydrant House merupakan salah satunya.

Proyek pembuatan Hydrant House terdapat banyak aktivitas-aktivitas besar yang membutuhkan waktu dan biaya yang tidak sedikit, jika dibandingkan dengan proyekproyek lain di internal perusahaan. Akan sangat membutuhkan perhitungan dan perencanaan yang rinci pada proyek Hydrant House tersebut. Sedangkan, sejauh ini Departemen Sipil PT XYZ dalam merencanakan proyek hanya berdasarkan metode scheduling sederhana dan pengalaman saja. Penggunaan metode perencanaan proyek tersebut dinilai kurang cukup, mengingat Departemen Sipil PT XYZ beberapa kali terkendala dalam waktu penyelesaian proyek, dimana waktu penyelesaian proyek tidak sesuai dengan waktu yang telah diestimasi sebelumnya. Oleh karena itu, dikhawatirkan akan terjadi keterlambatan pada proyek Hydrant House, jika dalam perencanaan proyek tidak segera diatasi dengan metode yang baik dan sistematis. Berikut pada gambar 4 adalah contoh schedule yang biasa digunakan Departemen Sipil dan tabel 1 adalah sebagian riwayat proyek yang telah dikerjakan pada kuartal I 2021 oleh Departemen Sipil PT XYZ.

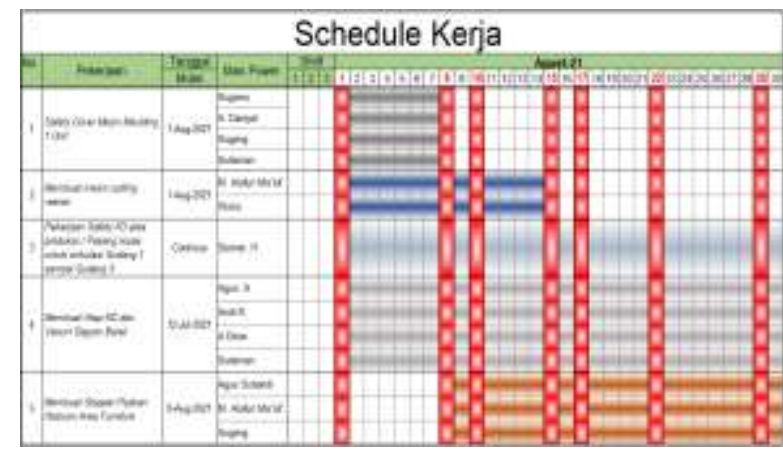

Gambar 4. Contoh Schedule Departemen Sipil PT $\mathrm{XYZ}$

Sumber : Departemen Sipil PT XYZ (2021)

Tabel 1. Riwayat Proyek Semester I 2021

\begin{tabular}{|c|c|c|c|c|}
\hline \multicolumn{5}{|c|}{$\begin{array}{c}\text { Riwayat Pelaksanaan Proyek Semester I } 2021 \\
\text { Ditinjau dari Waktu dan Biaya }\end{array}$} \\
\hline \multirow{2}{*}{$\begin{array}{l}\text { Nama } \\
\text { Proyek }\end{array}$} & \multicolumn{2}{|c|}{$\begin{array}{c}\text { Terkait Waktu } \\
\text { (Hari) }\end{array}$} & \multicolumn{2}{|c|}{ Terkait Biaya (Rp) } \\
\hline & Target & Realisasi & Target & Realisasi \\
\hline $\begin{array}{c}\text { Penambahan } \\
\text { Pos Pantau } \\
\text { Security }\end{array}$ & 32 & 36 & 61.727 .000 & 68.516 .000 \\
\hline $\begin{array}{c}\text { Pembuatan } \\
\text { Atap } \\
\text { Tambahan } \\
\text { Bagian } \\
\text { Vacum }\end{array}$ & 23 & 25 & 85.800 .000 & 92.525 .000 \\
\hline $\begin{array}{c}\text { Pembuatan } \\
\text { Tanki } \\
\text { Bagian } \\
\text { Vacum } \\
\end{array}$ & 14 & 15 & 87.267 .000 & 92.066 .000 \\
\hline $\begin{array}{l}\text { Modifikasi } \\
\text { Layout Area } \\
\text { Mesin } \\
\text { Trimming } \\
\text { Saw }\end{array}$ & 28 & 34 & 110.032 .000 & 114.433 .000 \\
\hline
\end{tabular}

Sumber : Departemen Sipil PT XYZ (2021)

Keterlambatan proyek yang ditunjukkan pada tabel 1 diakibatkan karena perencanaan proyek oleh Departemen Sipil PT XYZ hanya berdasarkan scheduling sederhana dan pengalaman belaka. Scheduling sederhana yang biasa dilakukan oleh Departemen Sipil PT XYZ hanya mencantumkan nama proyek dan waktu total yang dibutuhkan dalam menyelesaikan proyek tersebut. Padahal terkait detail kegiatan proyek, segmentasi kegiatan proyek, integrasi antar kegiatan proyek, dan waktu mulai sampai berakhir tiap kegiatan proyek sangat diperlukan dalam suatu perencanaan proyek. Hal-hal tersebut belum ada diperencanaan proyek Departemen Sipil PT XYZ sebelumnya, sehingga mengakibatkan keterlambatan suatu proyek.

Jadi, dalam melakukan penelitian terkait perencanaan proyek, penulis akan 
menggunakan metode PERT-Type System, yang mana dinilai cukup baik dalam hal perencanaan proyek karena dapat mengetahui detail kegiatan proyek, segmentasi kegiatan proyek, integrasi antar kegiatan proyek, dan waktu mulai sampai berakhir tiap kegiatan proyek. Dalam penggunaan metode PERT-Type System, penulis melakukan penelitian dengan alur secara umum: menguraikan kegiatan dalam proyek menggunakan Work Breakdown Structure (WBS), kemudian dilanjutkan mengintegrasikan dengan Jaringan Kerja (Network), mencari lintasan kritis menggunakan Critical Path Method (CPM), menghitung estimasi dan probabilitas menggunakan Program Evaluation and Review Technique (PERT).

\section{METODOLOGI PENELITIAN}

Metode yang akan digunakan dalam penelitian ini terkait manajemen proyek secara umum menggunakan pendekatan metode WBS, Network, CPM, dan PERT.

\subsection{Work Breakdown Structure (WBS)}

Work breakdown structure (WBS) dapat didefinisikan sebagai pengelompokkan kegiatan-kegiatan kerja yang ditunjukkan dalam bentuk chart yang berbentuk hierarki untuk mensegmentasi keseluruhan ruang lingkup suatu proyek kerja (Rev, 2003). Terdapat beberapa segmentasi kegiatan dalam WBS, yaitu :
a. Level 1, Proyek
b. Level 2, Tugas
c. Level 3, Sub-Tugas
d. Level 4, Paket Pekerjaan

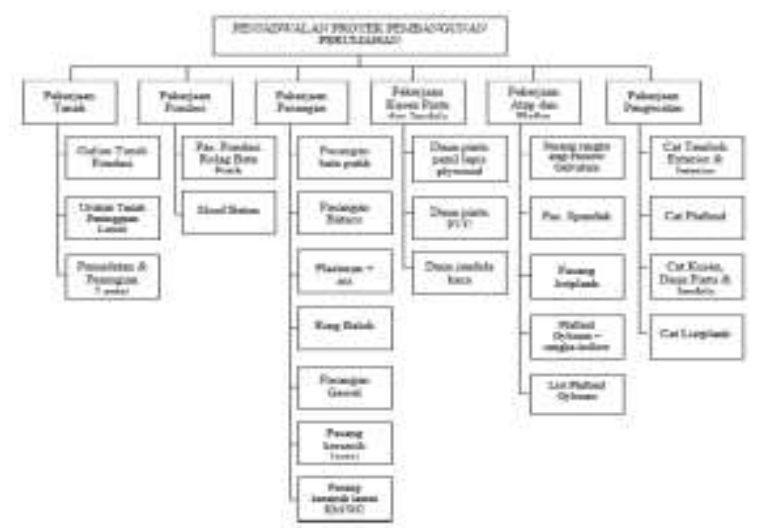

Gambar 5. Contoh Work Breakdown Structure Sumber : Fathoni (2020)

\subsection{Jaringan Kerja (Network)}

Jaringan Kerja (Network) merupakan tools dalam manajemen proyek yang biasa digunakan untuk perencanaan suatu proyek yang mengintegrasikan masing-masing kegiatan (Rani, 2016). Jaringan Kerja juga dapat mengetahui hubungan keterkaitan antar kegiatan (aktivitas) dalam suatu proyek. Jadi, ketergantungan dari masing-masing proyek dapat diketahui dengan jaringan kerja.

Dalam pembuatan Jaringan Kerja juga terdapat beberapa simbol yang perlu untuk diperhatikan. Berikut simbol dan pengertian dalam Jaringan Kerja yang dijelaskan cukup sistematis dalam jurnal Perdana dan Rahman (2019) :

a. Arrow (anak panah), merupakan sebuah simbol alur kegiatan yang memerlukan durasi (jangka waktu tertentu). Lihat gambar 6.

\section{Gambar 6. Arrow}

b. Node, merupakan lingkaran yang mendefinisikan sebuah tempat kegiatan dapat dimulai dan dapat diselesaikan. Lihat gambar 7.

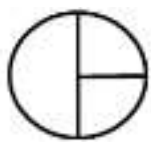

Gambar 7. Node

c. Dummy, merupakan simbol anak panah terputus-putus yang menyatakan kegiatan semu diperuntukkan membatasi mulainya kegiatan. Lihat gambar 8.

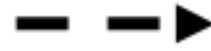

Gambar 8. Dummy

Pada gambar 9 merupakan contoh dari pengaplikasian Network.

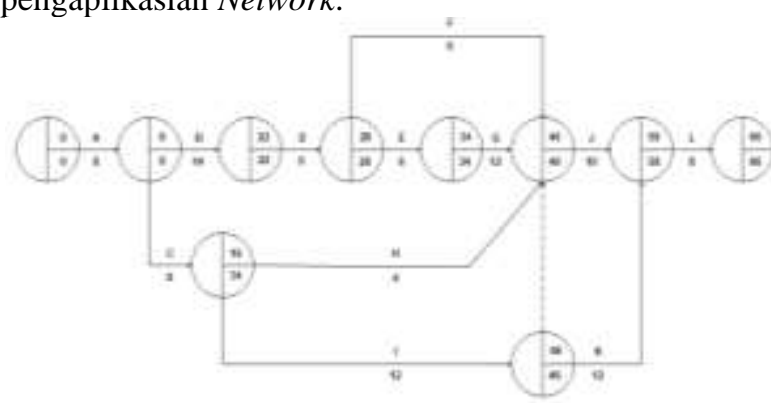

Gambar 9. Contoh Network

Sumber : Fathoni (2020)

2.3 Critical Path Method (CPM)

CPM pada dasarnya menitik beratkan pada persoalan keseimbangan antara waktu penyelesaian proyek-proyek. CPM membuat asumsi bahwa waktu dari kegiatan sudah diketahui pasti, sehingga hanya diperlukan satu 
faktor untuk tiap kegiatan. Pada CPM dipakai cara "deterministik", yaitu dalam mengestimasi hanya memerlukan satu angka (Heizer dan Rander, 2006).

Beberapa istilah yang digunakan dalam metode CPM ini adalah:

a. Earliest Start (ES)

ES dapat diartikan sebagai waktu tercepat suatu kegiatan atau aktivitas dapat dimulai.

b. Latest Start (LS)

LS dapat diartikan sebagai waktu paling lambat untuk memulai suatu kegiatan.

c. Earliest Finish (EF)

EF dapat diartikan sebagai waktu tercepat kegiatan dapat diselesaikan.

d. Latest Finish (LF)

LF dapat diartikan sebagai waktu paling lambat dalam menyelesaikan suatu kegiatan.

Berikut pada gambar 10 adalah contoh penerapan nilai ES, LS, EF, dan LF.

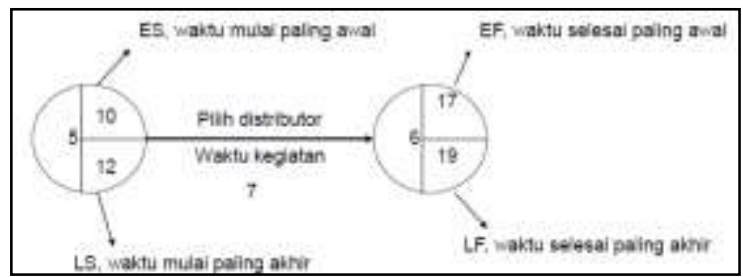

Gambar 10. Contoh Penerapan ES, LS, EF, LF Sumber : Fathoni (2020)

Sedangkan cara menghitung ES, EF, LS dan LF adalah sebagai berikut :

- $\quad \mathrm{EF}=\mathrm{ES}+$ waktu kegiatan (pilih nilai yang terbesar)

- $\quad \mathrm{LS}=\mathrm{LF}-$ waktu kegiatan (pilih nilai yang terkecil)

Menurut Rani (2016), Float merupakan waktu penundaan atau waktu untuk bisa terlambat dari suatu kegiatan. Float terdapat pada semua kegiatan yang tidak termasuk dalam lintasan kritis.

Ada 2 (dua) macam tipe float, yaitu:

a. Total Float

Total float diinterpretasikan sebagai sejumlah waktu untuk terlambat yang terdapat pada suatu kegiatan, bila mana kegiatan tersebut terlambat atau diperlambat pelaksanaannya, akan mempengaruhi waktu penyelesaian proyek secara keseluruhan.

Secara matematis : $\mathrm{TF}=\mathrm{LF}-\mathrm{ES}-\mathrm{D}$

b. Free Float

Free Float diinterpretasikan sebagai sejumlah waktu untuk bisa terlambat atau diperlambatnya suatu kegiatan tidak mempengaruhi waktu mulainya kegiatan yang berlangsung mengikutinya.

Secara matematis : FF $=\mathrm{EF}-\mathrm{ES}-\mathrm{D}$

Lintasan kegiatan atau aktivitas yang mempunyai Total Float $(\mathrm{TF})=0$, dapat diartikan sebagai lintasan kritis (Critical Path). Semua aktifitas atau kegiatan dalam lintasan kritis tidak bisa ditunda. Suatu penundaan akan menyebabkan umur proyek mundur.

\subsection{Program Evaluation and Review Technique (PERT) \\ Program Evaluation and Review} Technique (PERT) digunakan dalam melakukan penjadwalan, mengatur, dan mengkoordinasikan bagian-bagian kegiatan dalam suatu proyek.

Menurut Tarliah dan Dimyati (2013), PERT-Type System merupakan penggabungan kedua pendekatan metode PERT dan CPM. Perencanaan dan pengendalian proyek dapat mencapai optimal dengan bantuan PERT-Type System.

Kemudian, menurut Soeharto (2002), metode PERT mencakup tiga perkiraan waktu, yaitu:

a. Waktu pesimistic (tp), adalah waktu paling panjang yang mungkin diperlukan suatu kegiatan dalam proyek.

b. Waktu perkiraan paling mungkin (tm), adalah waktu penyelesaian kegiatankegiatan proyek yang paling memungkinkan, atau memiliki probabilitas paling tinggi.

c. Waktu Optimistic (to), adalah waktu tercepat yang dapat dilakukan untuk melaksanakan kegiatan suatu proyek.

Dalam pengaplikasian metode PERT ada beberapa rumus yang digunakan, dijelaskan cukup sistematis dalam jurnal Arsi, Setiawan, dan Adeswastoto (2021):

a. Menghitung waktu rata-rata/waktu yang diharapkan (te). Secara matematis :

$t e=\frac{a+4 m+b}{6}$

te :Waktu rata-rata/waktu yangdiharapkan

a : Waktu optimis

$\mathrm{m}$ : Waktu realistis

b : Waktu pesimis

Semakin besar nilai "v", semakin kecil "te" bisa dipercaya dan semakin tinggi kemungkinan kegiatan yang bersangkutan selesai lebih awal atau lebih lambat dari pada "te". Secara sederhana semakin jauh selisih antara "a" dan "b" semakin besar distribusinya dan semakin 
besar peluang waktu aktual pelaksanaan kegiatan secara signifikan berbeda dari waktu yang diharapkan "te", begitu juga berlaku sebaliknya.

b. Menghitung deviasi standar (S). Secara matematis :

$S=\frac{b-a}{6}$

S : Deviasi standar kegiatan

a : Waktu optimis

b : Waktu pesimi

c. Menghitung variasi kegiatan V(te). Secara matematis :

$V(t e)=S^{2}=\left(\frac{b-a}{6}\right)^{2}$

$\begin{array}{ll}\text { V(te) } & \text { : Varian kegiatan } \\ \mathrm{S} & \text { : Deviasi standar kegiatan } \\ \mathrm{a} & \text { : Waktu optimis } \\ \mathrm{b} & \text { : Waktu pesimis }\end{array}$

d. Menghitung peluang/probabilitas mencapai terget jadwal. Secara matematis :

$Z=\frac{T(d)-T E}{S}$

Z :Probabilitas kemungkinantercapainya target

$\mathrm{T}(\mathrm{d})$ : Target jadwal

TE : Jumlah waktu kegiatan kritis

$\mathrm{S}$ : Deviasi standar kegiatan

\section{HASIL DAN PEMBAHASAN}

Berdasarkan pada data kuantitatif maupun kualitatif yang penulis peroleh dari wawancara secara berkala kepada Man Power yang akan mengerjakan proyek dan observasi lapangan terkait perencanaan proyek Hydrant House, terdapat beberapa data penunjang penelitian ini. Data-data tersebut berupa: rencana rancangan urutan kegiatan proyek dan perkiraan waktunya (lihat pada tabel 2) dan gambar kerja proyek (lihat pada gambar 11, 12, 13)

Tabel 2. Estimasi Waktu Kegiatan dalam Proyek

\begin{tabular}{|c|l|c|}
\hline No. & \multicolumn{1}{|c|}{$\begin{array}{c}\text { Deskripsi Kegiatan-kegiatan } \\
\text { dalam Proyek }\end{array}$} & $\begin{array}{c}\text { Estimasi } \\
\text { Waktu } \\
\text { (hari) }\end{array}$ \\
\hline \hline 1 & $\begin{array}{l}\text { Pengukuran dan penandaan } \\
\text { lokasi }\end{array}$ & 1 \\
\hline 2 & Galian tanah dengan alat berat & 1 \\
\hline 3 & $\begin{array}{l}\text { Pemasangan anyaman bambu } \\
\text { (gedek) }\end{array}$ & 3 \\
\hline
\end{tabular}

\begin{tabular}{|c|c|c|}
\hline 4 & Pengurasan air & 2 \\
\hline 5 & $\begin{array}{l}\text { Pengeboran tanah untuk strauss } \\
\text { dan "cakar ayam" }\end{array}$ & 5 \\
\hline 6 & $\begin{array}{l}\text { Pemasangan strauss dan } \\
\text { pengecoran }\end{array}$ & 2 \\
\hline 7 & Pemasangan "cakar ayam" & 2 \\
\hline 8 & $\begin{array}{l}\text { Pengukuran dan pemadatan } \\
\text { "sirtu" untuk lantai kerja }\end{array}$ & 5 \\
\hline 9 & $\begin{array}{l}\text { Pembuatan rangka-rangka besi } \\
\text { (bawah) }\end{array}$ & 10 \\
\hline 10 & Pembuatan bekisting (1) & 3 \\
\hline 11 & Pengecoran lantai kerja $5-10 \mathrm{~cm}$ & 1 \\
\hline 12 & Pemasangan sloof (1) & 2 \\
\hline 13 & Pemasangan bekisting (2) & 2 \\
\hline 14 & Pemasangan wiremesh (1) & 3 \\
\hline 15 & Cor pondasi (ready mix) & 1 \\
\hline 16 & Pembuatan dinding $100 \mathrm{~cm}$ & 14 \\
\hline 17 & Pemasangan "sabukan" dan cor & 4 \\
\hline 18 & Pembuatan dinding $80 \mathrm{~cm}$ & 12 \\
\hline 19 & Pemasangan "sabukan" & 2 \\
\hline 20 & $\begin{array}{l}\text { Pemasangan bekisting luar dan } \\
\text { dalam (3) }\end{array}$ & 8 \\
\hline 21 & Pemasangan wiremesh (2) & 3 \\
\hline 22 & $\begin{array}{l}\text { Pengecoran lantai atas (ready } \\
\text { mix) }\end{array}$ & 1 \\
\hline 23 & Plester dinding dalam + "acian" & 10 \\
\hline 24 & pengecatan interior & 2 \\
\hline 25 & pemasangan pintu tandon & 3 \\
\hline 26 & Pemasangan sloof (2) & 1 \\
\hline 27 & Pemasangan bekesting dan cor & 4 \\
\hline 28 & $\begin{array}{l}\text { Pembuatan dinding dan } \\
\text { pemasangan pintu, dll. }\end{array}$ & 17 \\
\hline 29 & Pemasangan rangka atap dan atap & 3 \\
\hline 30 & $\begin{array}{l}\text { Plester dinding luar dan dalam + } \\
\text { "acian" }\end{array}$ & 5 \\
\hline
\end{tabular}




\begin{tabular}{|c|l|c|}
\hline 31 & $\begin{array}{l}\text { Pengecatan dinding luar dan } \\
\text { dalam }\end{array}$ & 1 \\
\hline 32 & Instalasi listrik & 4 \\
\hline 33 & $\begin{array}{l}\text { Persiapan instalasi pompa } \\
\text { hydrant }\end{array}$ & $\begin{array}{l}\text { Assembling instalasi pompa } \\
\text { hydrant }\end{array}$ \\
\hline
\end{tabular}

Sumber : Departemen Sipil PT XYZ (2021)

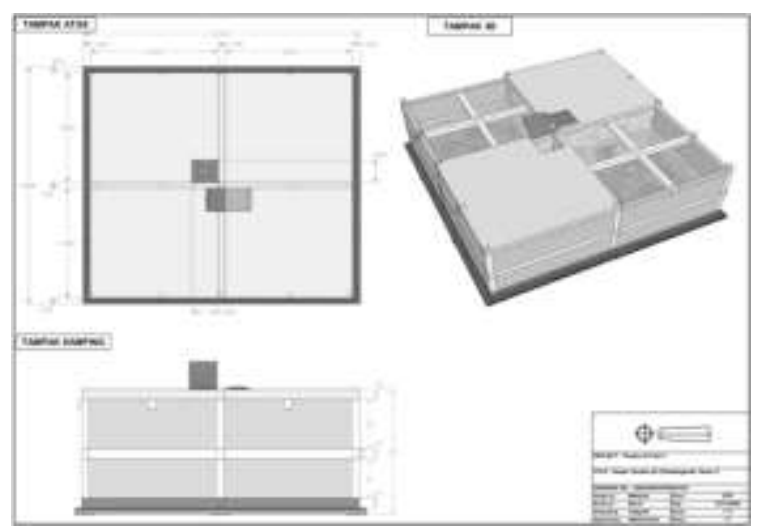

Gambar 11. Tandon Air Bawah Tanah Sumber: Departemen Sipil PT XYZ (2021)

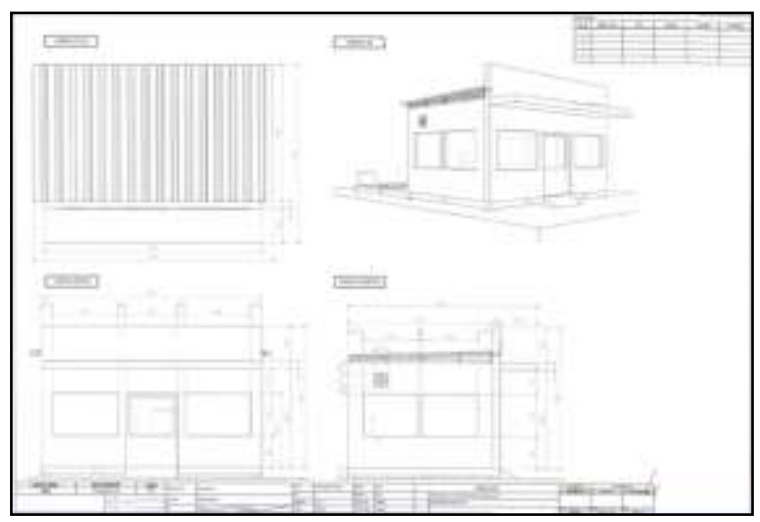

Gambar 12. House atau Pos Hydrant Sumber : Departemen Sipil PT XYZ (2021)

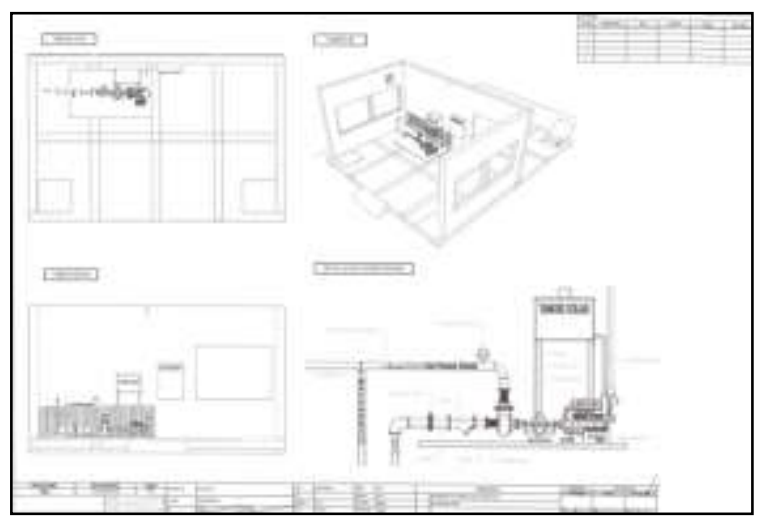

Gambar 13. Instalasi Pompa

Sumber : Departemen Sipil PT XYZ (2021)

\subsection{Pembuatan Work Breakdown Structure (WBS)}

Dari data kegiatan-kegiatan yang telah diperoleh, akan diuraikan dan diklasifikasikan berdasarkan segementasi atau level dari masing-masing kegiatan tersebut. Dengan mengurai kegiatan-kegiatan dapat mempermudah mengetahui penyusunan network nantinya. Berikut pada gambar 13 adalah Work Breakdown Structure (WBS) dalam proyek Hydrant House.

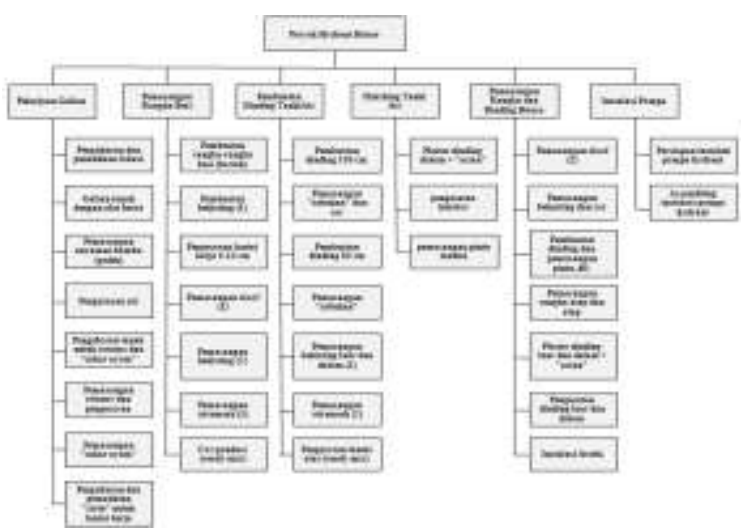

Gambar 13. Work Breakdown Structure

\subsection{Menguraikan Ketergantungan antar Masing-masing Kegiatan Proyek}

Pada tahap ini ditentukan hubungan tiap kegiatan dengan kegiatan lainnya. Tahap penentuan ketergantungan kegiatan ini dapat dilakukan dengan observasi dan wawancara kepada Man Power dan validasi dari Team Leader Departemen Sipil. Lihat pada tabel 3.

Tabel 3. Ketergantungan Antar Kegiatan Proyek

\begin{tabular}{|c|c|l|c|c|}
\hline Kode & No. & $\begin{array}{l}\text { Deskripsi Kegiatan- } \\
\text { kegiatan dalam } \\
\text { Proyek }\end{array}$ & Simbol & $\begin{array}{c}\text { Kegiatan } \\
\text { Pendahulu }\end{array}$ \\
\hline \hline A & \multicolumn{2}{|l|}{ Galian } & - & - \\
\hline & 1 & $\begin{array}{l}\text { Pengukuran dan } \\
\text { penandaan lokasi }\end{array}$ & A1 & - \\
\hline & 2 & $\begin{array}{l}\text { Galian tanah dengan } \\
\text { alat berat }\end{array}$ & A2 & A1 \\
\hline & 3 & $\begin{array}{l}\text { Pengurasan air } \\
\text { Aemasangan }\end{array}$ & A2 \\
\hline & 4 & $\begin{array}{l}\text { Anyaman bambu } \\
\text { (gedek) }\end{array}$ & A4 \\
\hline
\end{tabular}




\begin{tabular}{|c|c|c|c|c|}
\hline & 5 & $\begin{array}{l}\text { Pengeboran tanah } \\
\text { untuk strauss dan } \\
\text { "cakar ayam" }\end{array}$ & A5 & A4 \\
\hline & 6 & $\begin{array}{l}\text { Pemasangan strauss } \\
\text { dan pengecoran }\end{array}$ & A6 & $\mathrm{A} 5, \mathrm{~B} 2$ \\
\hline & 7 & $\begin{array}{l}\text { Pemasangan "cakar } \\
\text { ayam" }\end{array}$ & A7 & A6 \\
\hline & 8 & $\begin{array}{l}\text { Pengukuran dan } \\
\text { pemadatan "sirtu" } \\
\text { untuk lantai kerja }\end{array}$ & A8 & A7 \\
\hline B & \multicolumn{2}{|c|}{$\begin{array}{l}\text { Pemasangan rangka- } \\
\text { rangka besi }\end{array}$} & - & - \\
\hline & 1 & $\begin{array}{l}\text { Pembuatan rangka- } \\
\text { rangka besi (bawah) }\end{array}$ & B1 & - \\
\hline & 2 & $\begin{array}{l}\text { Pembuatan bekisting } \\
\text { (1) }\end{array}$ & B2 & B1 \\
\hline & 3 & $\begin{array}{l}\text { Pengecoran lantai } \\
\text { kerja } 5-10 \mathrm{~cm}\end{array}$ & B3 & A7 \\
\hline & 4 & Pemasangan sloof (1) & B4 & B3 \\
\hline & 5 & $\begin{array}{l}\text { Pemasangan } \\
\text { bekisting (2) }\end{array}$ & B5 & B3 \\
\hline & 6 & $\begin{array}{l}\text { Pemasangan } \\
\text { wiremesh (1) }\end{array}$ & B6 & B4, B5 \\
\hline & 7 & $\begin{array}{l}\text { Cor pondasi (ready } \\
\text { mix) }\end{array}$ & B7 & B6 \\
\hline \multirow[t]{8}{*}{$\mathbf{C}$} & \multicolumn{2}{|c|}{$\begin{array}{l}\text { Pembuatan dinding tanki } \\
\text { air }\end{array}$} & - & - \\
\hline & 1 & $\begin{array}{l}\text { Pembuatan dinding } \\
100 \mathrm{~cm}\end{array}$ & $\mathrm{C} 1$ & B7 \\
\hline & 2 & $\begin{array}{l}\text { Pemasangan } \\
\text { "sabukan" dan cor }\end{array}$ & $\mathrm{C} 2$ & $\mathrm{C} 1$ \\
\hline & 3 & $\begin{array}{l}\text { Pembuatan dinding } \\
80 \mathrm{~cm}\end{array}$ & $\mathrm{C} 3$ & $\mathrm{C} 2$ \\
\hline & 4 & $\begin{array}{l}\text { Pemasangan } \\
\text { "sabukan" }\end{array}$ & $\mathrm{C} 4$ & $\mathrm{C} 3$ \\
\hline & 5 & $\begin{array}{l}\text { Pemasangan } \\
\text { bekisting luar dan } \\
\text { dalam (3) }\end{array}$ & C5 & $\mathrm{C} 4$ \\
\hline & 6 & $\begin{array}{l}\text { Pemasangan } \\
\text { wiremesh (2) }\end{array}$ & C6 & C5 \\
\hline & 7 & $\begin{array}{l}\text { Pengecoran lantai } \\
\text { atas (ready mix) }\end{array}$ & C7 & C6 \\
\hline \multirow[t]{4}{*}{ D } & \multicolumn{2}{|c|}{ Finishing tanki air } & - & - \\
\hline & 1 & $\begin{array}{l}\text { Plester dinding } \\
\text { dalam + "acian" }\end{array}$ & D1 & $\mathrm{C} 7$ \\
\hline & 2 & pengecatan interior & D2 & D1 \\
\hline & 3 & $\begin{array}{l}\text { pemasangan pintu } \\
\text { tandon }\end{array}$ & D3 & D2 \\
\hline \multirow[t]{2}{*}{$\mathbf{E}$} & \multicolumn{2}{|c|}{$\begin{array}{l}\text { Pemasangan rangka dan } \\
\text { dinding hydrant house }\end{array}$} & - & - \\
\hline & 1 & Pemasangan sloof (2) & E1 & $\mathrm{C} 7$ \\
\hline
\end{tabular}

\begin{tabular}{|c|c|l|c|c|}
\hline & 2 & $\begin{array}{l}\text { Pemasangan } \\
\text { bekesting dan cor }\end{array}$ & E2 & E1, D3 \\
\hline & 3 & $\begin{array}{l}\text { Pembuatan dinding } \\
\text { dan pemasangan } \\
\text { pintu, dll. }\end{array}$ & E3 & E2 \\
\hline & 5 & $\begin{array}{l}\text { Pemasangan rangka } \\
\text { atap dan atap }\end{array}$ & E4 & E3 \\
\hline dan dalam + "acian" & E5 & E4 \\
\hline F & Instalasi pompa & $\begin{array}{l}\text { Pengecatan dinding } \\
\text { luar dan dalam }\end{array}$ & E6 & E5 \\
\hline & 1 & $\begin{array}{l}\text { Instalasi listrik } \\
\text { pompa hydrant }\end{array}$ & E7 & E5 \\
\hline pompa hydrant & F2 & E6, F1 \\
\hline & 1 & $\begin{array}{l}\text { Persiapan instalasi } \\
\text { Assembling instalasi }\end{array}$ & E7 \\
\hline
\end{tabular}

\subsection{Perhitungan Waktu yang Diharapkan} (Te), Deviasi (S), dan Variansi (V)

Sebelum menghitung nilai $T e, S$, dan $V$, akan diuraikan terlebih dahulu nilai waktu pesimistic (tp), waktu perkiraan paling mungkin atau most likely (tm), dan waktu Optimistic (to) berdasarkan wawancara dengan Man Power pengerjaan proyek Hydrant House dan validasi dari Team Leader Departemen Sipil.

Kemudian, setelah mengetahui semua kegiatan dan ketergantungannya, langkah selanjutnya menentukan waktu yang diharapkan $(T e)$, Standar deviasi $(S)$ dan varians $(V)$ untuk setiap kegiatan. Tujuannya adalah untuk mengetahui kepastian waktu setiap kegiatan dan berapa besar penyimpangan dari setiap kegiatan tersebut. Adapun cara perhitungan waktu yang diharapkan (Te), Standar deviasi $(S)$ dan varians $(V)$ untuk setiap kegiatan adalah berdasarkan Rumus. Berikut adalah salah satu contoh perhitungan kegiatan A5, yang nantinya akan penulis rekap dalam bentuk tabel 4 .

Menghitung waktu rata-rata/waktu yang diharapkan $(T e)$. Secara matematis :

$$
\begin{aligned}
& t e=\frac{4+(4 \times 5)+6}{6} \\
& t e=5 \text { hari }
\end{aligned}
$$

Menghitung standar deviasi (S). Secara matematis :

$$
\begin{aligned}
& S=\frac{6-4}{6} \\
& S=0.33
\end{aligned}
$$

Menghitung variasi kegiatan (V). Secara matematis :

$$
\begin{aligned}
& V(t e)=S^{2}=\left(\frac{6-4}{6}\right)^{2} \\
& V(t e)=0.33^{2}
\end{aligned}
$$




$$
V(t e)=0.11
$$

Tabel 4. Nilai $T e$ (Waktu yang Diharapkan), $S$ (Standar Deviasi), dan $V$ (Varians)

\begin{tabular}{|c|c|c|c|c|c|c|c|}
\hline No. & Simbol & tp & $\mathrm{tm}$ & to & $T e$ & $S$ & $V$ \\
\hline 1 & A1 & 2 & 1 & 1 & 1,17 & 0,17 & 0,03 \\
\hline 2 & A2 & 2 & 1 & 1 & 1,17 & 0,17 & 0,03 \\
\hline 3 & A3 & 5 & 3 & 3 & 3,33 & 0,33 & 0,11 \\
\hline 4 & A4 & 2 & 2 & 1 & 1,83 & 0,17 & 0,03 \\
\hline 5 & A5 & 6 & 5 & 4 & 5,00 & 0,33 & 0,11 \\
\hline 6 & A6 & 3 & 2 & 2 & 2,17 & 0,17 & 0,03 \\
\hline 7 & A7 & 2 & 2 & 1 & 1,83 & 0,17 & 0,03 \\
\hline 8 & A8 & 6 & 5 & 4 & 5,00 & 0,33 & 0,11 \\
\hline 9 & B1 & 12 & 10 & 10 & 10,33 & 0,33 & 0,11 \\
\hline 10 & B2 & 3 & 3 & 2 & 2,83 & 0,17 & 0,03 \\
\hline 11 & B3 & 2 & 1 & 1 & 1,17 & 0,17 & 0,03 \\
\hline 12 & B4 & 3 & 2 & 2 & 2,17 & 0,17 & 0,03 \\
\hline 13 & B5 & 2 & 2 & 1 & 1,83 & 0,17 & 0,03 \\
\hline 14 & B6 & 3 & 3 & 2 & 2,83 & 0,17 & 0,03 \\
\hline 15 & B7 & 2 & 1 & 1 & 1,17 & 0,17 & 0,03 \\
\hline 16 & $\mathrm{C} 1$ & 16 & 14 & 13 & 14,17 & 0,50 & 0,25 \\
\hline 17 & $\mathrm{C} 2$ & 5 & 4 & 3 & 4,00 & 0,33 & 0,11 \\
\hline 18 & $\mathrm{C} 3$ & 14 & 12 & 11 & 12,17 & 0,50 & 0,25 \\
\hline 19 & $\mathrm{C} 4$ & 3 & 2 & 1 & 2,00 & 0,33 & 0,11 \\
\hline 20 & C5 & 9 & 8 & 7 & 8,00 & 0,33 & 0,11 \\
\hline 21 & C6 & 3 & 3 & 2 & 2,83 & 0,17 & 0,03 \\
\hline 22 & C7 & 2 & 1 & 1 & 1,17 & 0,17 & 0,03 \\
\hline 23 & D1 & 11 & 10 & 9 & 10,00 & 0,33 & 0,11 \\
\hline 24 & D2 & 2 & 2 & 1 & 1,83 & 0,17 & 0,03 \\
\hline 25 & D3 & 4 & 3 & 3 & 3,17 & 0,17 & 0,03 \\
\hline 26 & E1 & 2 & 1 & 1 & 1,17 & 0,17 & 0,03 \\
\hline 27 & E2 & 5 & 4 & 3 & 4,00 & 0,33 & 0,11 \\
\hline 28 & E3 & 20 & 17 & 17 & 17,50 & 0,50 & 0,25 \\
\hline 29 & E4 & 4 & 3 & 3 & 3,17 & 0,17 & 0,03 \\
\hline 30 & E5 & 6 & 5 & 4 & 5,00 & 0,33 & 0,11 \\
\hline 31 & E6 & 2 & 1 & 1 & 1,17 & 0,17 & 0,03 \\
\hline 32 & E7 & 4 & 3 & 3 & 3,17 & 0,17 & 0,03 \\
\hline 33 & $\mathrm{~F} 1$ & 6 & 4 & 4 & 4,33 & 0,33 & 0,11 \\
\hline 34 & F2 & 9 & 7 & 7 & 7,33 & 0,33 & 0,11 \\
\hline
\end{tabular}

\subsection{Pembuatan Network dan penentuan Lintasan Kritis}

Tahap selanjutnya adalah membuat Network atau Jaringan Kerja. Dalam tahapan ini, segmentasi dari WBS dan penentuan waktu $t p$, tm, to, $T e$, dan $V$ dari masing-masing kegiatan diintegrasikan dengan membuat Network dan menentukan lintasan kritis. Berikut pada gambar 14, 15, 16, dan 17 adalah penerapan Network.

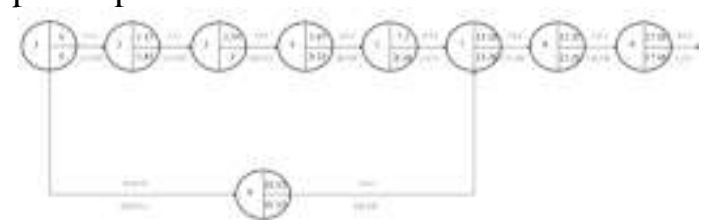

Gambar 14. Network

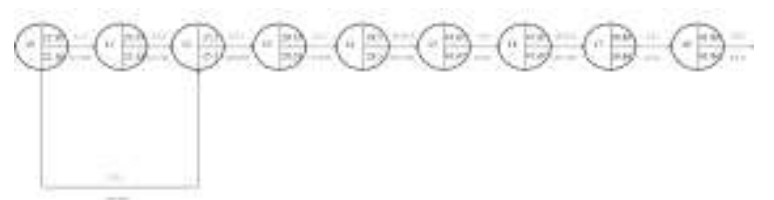

Gambar 15. Network Lanjutan (1)

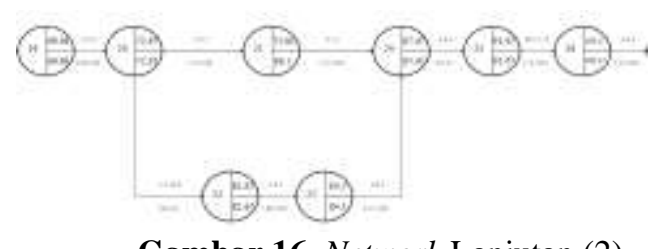

Gambar 16. Network Lanjutan (2)

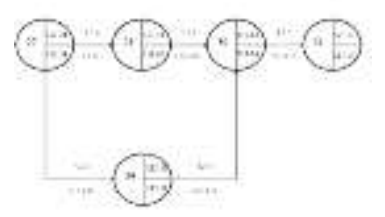

Gambar 17. Network Lanjutan (3)

Setelah pembuatan Network, maka akan dibuat rekap untuk menentukan lintasan kritis. Lintasan yang mempunyai Total Float $(\mathrm{TF})=0$, dapat diartikan sebagai lintasan kritis (Critical Path). Semua kegiatan dalam lintasan kritis tidak bisa ditunda. Suatu penundaan akan menyebabkan umur proyek mundur. Lintasan kritis pada tabel 5 adalah yang dilalui oleh alur 1-6-7-8-9-10-11-12-13-14-15-16-17-18-19-2022-23-24-25-26-27-29-30-31.

Tabel 5. Rekap Lintasan Kritis

\begin{tabular}{|c|c|c|c|c|c|c|}
\hline $\begin{array}{c}\text { Simb } \\
\text { ol }\end{array}$ & Te & ES & EF & LS & LF & $\begin{array}{c}\text { TF } \\
\text { (LF-ES- } \\
\text { Te })\end{array}$ \\
\hline \hline A1 & 1,17 & 0,00 & 1,17 & 0,00 & 1,83 & 0,66 \\
\hline A2 & 1,17 & 1,17 & 2,34 & 1,17 & 3,00 & 0,66 \\
\hline A3 & 3,33 & 2,34 & 5,67 & 2,34 & 6,33 & 0,66 \\
\hline A4 & 1,83 & 5,67 & 7,50 & 5,67 & 8,16 & 0,66 \\
\hline A5 & 5,00 & 7,50 & 12,50 & 7,50 & 12,50 & 0,00 \\
\hline A6 & 2,17 & 12,50 & 15,33 & 12,50 & 15,33 & 0,66 \\
\hline
\end{tabular}




\begin{tabular}{|c|c|c|c|c|c|c|}
\hline A7 & 1,83 & 15,33 & 17,16 & 15,33 & 17,16 & 0,00 \\
\hline A8 & 5,00 & 17,16 & 22,16 & 17,16 & 22,16 & 0,00 \\
\hline B1 & $\begin{array}{c}10,3 \\
3\end{array}$ & 0,00 & 10,33 & 0,00 & 10,33 & 0,00 \\
\hline B2 & 2,83 & 10,33 & 13,16 & 10,33 & 13,16 & 0,00 \\
\hline B3 & 1,17 & 22,16 & 23,33 & 22,16 & 23,33 & 0,00 \\
\hline B4 & 2,17 & 23,33 & 25,50 & 23,33 & 25,50 & 0,00 \\
\hline B5 & 1,83 & 22,16 & 25,50 & 22,16 & 25,50 & 1,51 \\
\hline B6 & 2,83 & 25,50 & 28,33 & 25,50 & 28,33 & 0,00 \\
\hline B7 & 1,17 & 28,33 & 29,50 & 28,33 & 29,50 & 0,00 \\
\hline $\mathrm{C} 1$ & $\begin{array}{c}14,1 \\
7 \\
\end{array}$ & 29,50 & 43,67 & 29,50 & 43,67 & 0,00 \\
\hline C2 & 4,00 & 43,67 & 47,67 & 43,67 & 47,67 & 0,00 \\
\hline C3 & $\begin{array}{c}12,1 \\
7 \\
\end{array}$ & 47,67 & 59,83 & 47,67 & 59,83 & 0,00 \\
\hline C4 & 2,00 & 59,83 & 61,83 & 59,83 & 61,83 & 0,00 \\
\hline C5 & 8,00 & 61,83 & 69,83 & 61,83 & 69,83 & 0,00 \\
\hline C6 & 2,83 & 69,83 & 72,67 & 69,83 & 72,67 & 0,00 \\
\hline C7 & 1,17 & 72,67 & 73,84 & 72,67 & 86,50 & 12,67 \\
\hline D1 & $\begin{array}{c}10,0 \\
0\end{array}$ & 72,67 & 82,67 & 72,67 & 82,67 & 0,00 \\
\hline D2 & 1,83 & 82,67 & 84,50 & 82,67 & 84,50 & 0,00 \\
\hline D3 & 3,17 & 84,50 & 87,67 & 84,50 & 87,67 & 0,00 \\
\hline E1 & 1,17 & 73,84 & 87,67 & 86,50 & 87,67 & 12,66 \\
\hline E2 & 4,00 & 87,67 & 91,67 & 87,67 & 91,67 & 0,00 \\
\hline E3 & $\begin{array}{c}17,5 \\
0\end{array}$ & 91,67 & $\begin{array}{c}109,1 \\
7\end{array}$ & 91,67 & $\begin{array}{c}109,1 \\
7\end{array}$ & 0,00 \\
\hline E4 & 3,17 & $\begin{array}{c}109,1 \\
7 \\
\end{array}$ & $\begin{array}{c}112,3 \\
4 \\
\end{array}$ & $\begin{array}{c}109,1 \\
7 \\
\end{array}$ & $\begin{array}{c}112,3 \\
4 \\
\end{array}$ & 0,00 \\
\hline E5 & 5,00 & $\begin{array}{c}112,3 \\
4 \\
\end{array}$ & $\begin{array}{c}117,3 \\
4 \\
\end{array}$ & $\begin{array}{c}112,3 \\
4 \\
\end{array}$ & $\begin{array}{c}118,6 \\
7 \\
\end{array}$ & 1,33 \\
\hline E6 & 1,17 & $\begin{array}{c}118,6 \\
7 \\
\end{array}$ & $\begin{array}{c}119,8 \\
4 \\
\end{array}$ & $\begin{array}{c}117,3 \\
4 \\
\end{array}$ & $\begin{array}{c}119,8 \\
4 \\
\end{array}$ & 0,00 \\
\hline E7 & 3,17 & $\begin{array}{c}112,3 \\
4\end{array}$ & $\begin{array}{c}115,5 \\
0\end{array}$ & $\begin{array}{c}112,3 \\
4\end{array}$ & $\begin{array}{c}115,5 \\
0\end{array}$ & 0,00 \\
\hline F1 & 4,33 & $\begin{array}{c}115,5 \\
0 \\
\end{array}$ & $\begin{array}{c}119,8 \\
4\end{array}$ & $\begin{array}{c}115,5 \\
0\end{array}$ & $\begin{array}{c}119,8 \\
4\end{array}$ & 0,00 \\
\hline F2 & 7,33 & $\begin{array}{c}119,8 \\
4\end{array}$ & $\begin{array}{c}127,1 \\
7\end{array}$ & $\begin{array}{c}119,8 \\
4\end{array}$ & $\begin{array}{c}127,1 \\
7 \\
\end{array}$ & 0,00 \\
\hline
\end{tabular}

Berdasarkan tabel distribusi normal baku, maka nilai $\mathrm{Z}=0.1210=12 \%$. Jadi, jika proyek dikerjakan selama 120 hari atau 3 bulan, maka probabilitas keberhasilannya adalah sebesar $12 \%$.

Kemudian, penulis mencoba mencari tahu berapa hari yang dibutuhkan, jika probabilitas atau peluang diubah menjadi $95 \%$. Maka nilai Z yang bersesuaian adalah 1.645.

$$
\begin{aligned}
& 1.645=\frac{T(d)-128}{6.83}=139.23 \text { hari, atau } \\
& \text { dibulatkan menjadi } 140 \text { hari. }
\end{aligned}
$$

\section{KESIMPULAN}

Dari apa yang telah diuraikan dan dipaparkan pada perhitungan sebelumnya, dapat disimpulkan sebagai berikut :

a. Kegiatan-kegiatan dalam proyek Hydrant House dapat diketahui dengan jelas mengenai segmentasi dan level dengan mengacu pada Work Breakdown Structure (WBS). Sehingga dengan adanya WBS diharapkan dapat lebih memahami konteks dari masing-masing kegiatan. Terdapat tiga level (proyek, tugas, sub-tugas) dari proyek Hydrant House dan dari tiga level tersebut terdiri dari 34 sub-tugas.

b. Terkait lama proyek dapat terselesaikan adalah selama 120 hari, dengan probabilitas keberhasilan sebesar $12 \%$. Oleh karena itu, penulis memberi opsi peluang keberhasilan terselesainya proyek sebesar $95 \%$ adalah selama 139.23 hari atau 140 hari. Jadi, agar dapat tercapai penyelesaian proyek, maka proyek paling tidak harus dikerjakan selama 140 hari. Karena probabilitas penyelesaian 140 hari lebih besar (95\%), jika dibandingkan dengan probabilitas penyelesaian 120 hari $(12 \%)$.

c. Dengan membuat jaringan kerja dan menghitung nilai $\mathrm{ES}, \mathrm{EF}$, LS, dan LF, maka dapat diketahui lintasan kritis pada proyek Hydrant House adalah yang dilalui oleh alur 1-6-7-8-9-10-11-12-13-14-15-1617-18-19-20-22-23-24-25-26-27-29-30-31. Oleh karena itu, dalam lintasan tersebut tidak bisa ditunda. Suatu penundaan akan menyebabkan umur proyek mundur.

\section{DAFTAR PUSTAKA}

Antika, O. R. (2018). Analisis Biaya dan Waktu pada Crashing dengan Menggunakan Metode Shift (Analysis of Costs and Time in Crasching by Using Shift Method.UII. 
Departemen Sipil PT XYZ, diwawancarai oleh penulis, September 2021, Gresik.

Dimyati, D. H., \& Nurjaman, K. (2014). Manajemen Proyek. Yogyakarta: Pustaka Setia.

Fathoni, M. Z. (2020). Konsep dan Pengertian Manpro [Presentasi PowerPoint].

Fathoni, M. Z. (2020). Perencanaan Proyek [Presentasi PowerPoint].

Fathoni, M. Z. (2020). Penjadwalan Proyek [Presentasi PowerPoint].

Fathoni, M. Z. (2020). Minimasi biaya dan alokasi SD [Presentasi PowerPoint].

Heizer, J. \& Rander, B. (2006). Manajemen Operasi, Edisi Ketujuh. Jakarta: Salemba Empat.

Perdana, S. \& Rahman, A. (2019). Penerapan Manajemen Proyek dengan Metode CPM (Critical Patch Method) pada Proyek Pembangunan SPBE. Jurnal Pengabdian Kepada Masyarakat, 3(1). 242-250.

Project Management Institute. (2004). A Guide to the Project Management of Body Knowledge (PMBOK Guide). USA: Project Management Institute.

Rani, H. A. (2016). Manajemen Proyek Konstruksi. Yogyakarta: Dee Publish.

Rantesalu, S. (2019). Evaluasi Waktu Pelaksanaan Pekerjaan Pada Proyek Pembangunan Gedung BAPPEDA Provinsi Kalimantan Utara Tahap III. Potensi: Jurnal Sipil Politeknik, 21(1). 42-46.

Rev, E. (2003). Work Breakdown Structure. America: U.S. Department of Energy.

Siswanto, A. B \& Salim, M. A. (2019). Manajemen Proyek. Semarang: CV Pilar Nusantara.

Soeharto, I. (1997). Manajemen Konstruksi dari Konseptual sampai Operasional. Jakarta: Erlangga.

Soeharto, I. (2002). Studi Kelayaan Proyek Industri. Jakarta: Erlangga.

Tarliah, T. D. \& Dimyati, A. (2013). Operations Research (Model-model Pengambilan Keputusan). Bandung: Sinar BaruAlgesindo 